\title{
Progressions
}

Author reflections on developments since the publication of "Neurons Containing Hypocretin (Orexin) Project to Multiple Neuronal Systems," by Christelle Peyron, Devin K. Tighe, Anthony N. van den Pol, Luis de Lecea, H. Craig Heller, J. Gregor Sutcliffe and Thomas S. Kilduff. (1998) J Neurosci 18:9996-10015.

\section{Mapping the Hypocretin/Orexin Neuronal System: An Unexpectedly Productive Journey}

\author{
Christelle Peyron $^{1}$ and Thomas S. Kilduff ${ }^{2}$ \\ ${ }^{1}$ Center for Research in Neuroscience of Lyon, Sleep team, Centre National de la Recherche Scientifique, Unité Mixte de Recherche 5292, Institut National \\ de la Santé et de la Recherche Médicale U1028, Université Claude Bernard Lyon 1, Lyon, France, and ²Center for Neuroscience, Biosciences Division, SRI \\ International, Menlo Park, California 94025
}

Early in 1998, we (de Lecea et al., 1998) and others (Sakurai et al., 1998) described the same hypothalamic neuropeptides, respectively called the hypocretins or orexins, which were discovered using two different approaches. In December of that year, we published the subject of this commentary in the Journal of Neuroscience: a highly detailed anatomical description of the extensive axonal projections of the hypocretin/orexin neurons. Although the function of this system was unknown at the time, a large body of literature today attests that the hypocretin/orexin neuropeptides play important roles in multiple physiological functions, particularly in sleep/wake regulation. Neuroanatomical studies are rarely frontline news, but the citation rate of this paper underscores the critical nature of such basic research. Based in part on this detailed description, the hypocretin/orexin neuropeptides have since been studied in many different areas of neuroscience research, including sleep/wake regulation, feeding, addiction, reward and motivation, anxiety and depression, cardiovascular regulation, pain, migraine, and neuroendocrine regulation, including reproduction. Thus, this paper has had a surprisingly broad impact on neuroscience research, particularly since it was originally rejected by the Journal!

Neuroanatomists are fortunate researchers: their role is to image the beauty of nature and reveal its complexity. Images obtained from their observations are often truly amazing, and their interpretations are often critical for subsequent functional studies. Unfortunately, with the exception of ground-breaking techniques, such as Brainbow mice or Clarity, neuroanatomy rarely appears to be high-profile news to editors or publishers. Consequently, neuroanatomical descriptions are often published in lower impact journals, although they are frequently highly cited. However, knowledge of the interactions among neuronal structures and subgroups of neurons (the connectome) is clearly essential for the understanding of brain function. As described below, our paper "Neurons containing the hypocretin (orexin) precursor project to multiple neuronal systems" exemplifies many of these points (Peyron et al., 1998).

Our December 1998 paper provided the other "bookend" for the description of the hypocretins (de Lecea et al., 1998) and the orexins (Sakurai et al., 1998), which had occurred in January and

\footnotetext{
Received 0ct. 17, 2016; accepted 0ct. 25, 2016.

This work was supported by National Institutes of Health R01 NS077408 and R01 NS098813 to T.S.K. and Centre National de la Recherche Scientifique and ANR14-CE14-0016-02 to C.P.

The authors declare no competing financial interests.

Correspondence should be addressed to Dr. Christelle Peyron, CRNL, CNRS UMR5292, Université Claude Bernard Lyon 1, 7 rue Paradin, 69372, Lyon, France. E-mail: peyron@sommeil.univ-lyon1.fr.

DOI:10.1523/JNEUROSCI.1708-16.2016

Copyright $\odot 2017$ the authors $\quad 0270-6474 / 17 / 372268-05 \$ 15.00 / 0$
}

February, respectively, of that year. In this paper, we provided the first detailed description of the extensive axonal arborization of the neurons expressing the hypocretin/orexin neuropeptides. Although an unequivocal functional role for these neuropeptides had yet to be demonstrated at the time of our submission in May 1998, we were convinced of the fundamental importance of this system because of the very restricted localization of its cell bodies to the tuberal hypothalamus, a brain region with a key role in multiple physiological functions, and the extensive distribution of their axonal projections. Indeed, Reviewer 1 of our paper stated that "the discussion is rather speculative since no functional data are available," and Reviewer 2 stated that "the authors have only done an immunocytochemical study . . . It is descriptive, and provides some handwaving arguments in the discussion to try to bring some functional relevance. As a result, this is the sort of paper that one typically finds in subspecialty journals, but perhaps a rung or two short of what is expected in the Journal of Neuroscience." Consequently, on June 24, our manuscript was rejected and we were devastated!

Ordinarily, one would take such criticisms at face value and seek a "more appropriate venue" for publication. However, Reviewer 2 had also stated, “. . this is a very competitive field and other papers reporting similar findings may already be somewhere in the publishing process," suggesting to us that Reviewer 2 was undoubtedly privy to other information and may even have had a conflict of interest in this review. Consequently, T.S.K. 


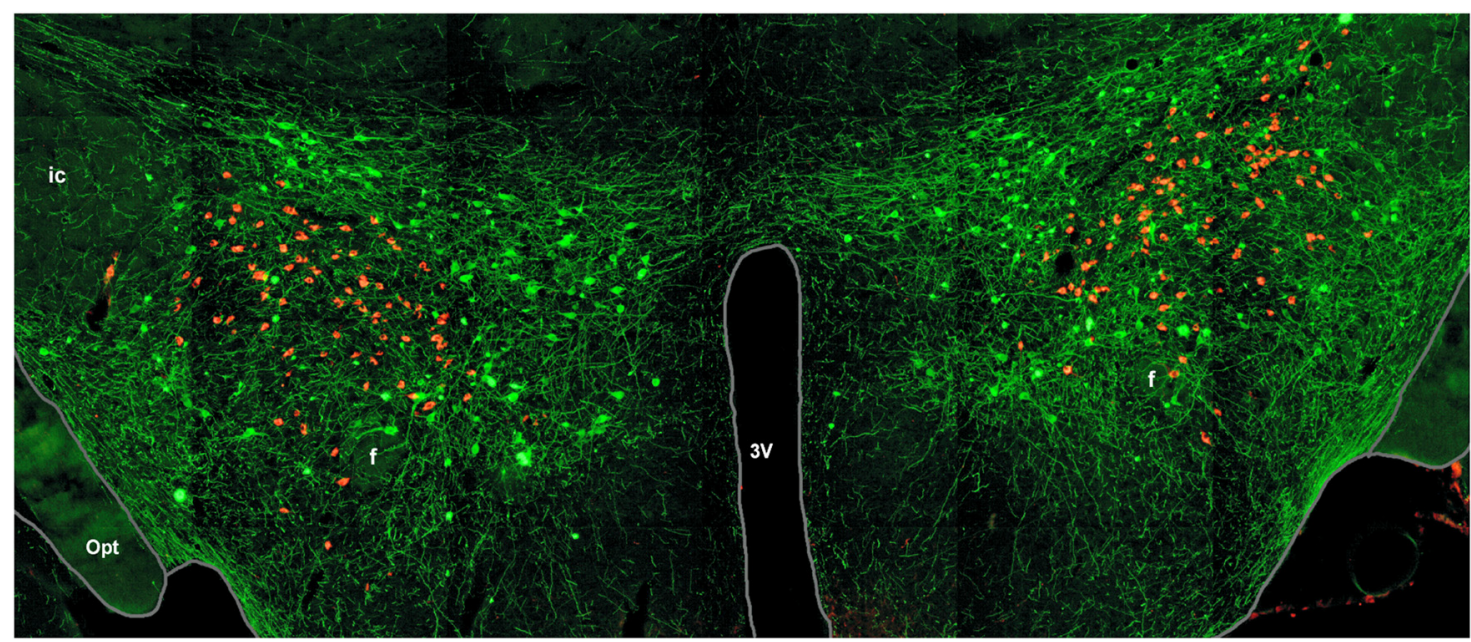

Figure 1. Illustration of the neuronal populations hypocretin/orexin (orange) and MCH (green) in the tuberal hypothalamus on a coronal section of a mouse brain. 3V, Third ventricle; ic, internal capsule; f, fornix; opt, optic tract.

submitted an appeal to the Journal of Neuroscience. Prof. T. Carew, senior editor at that time, agreed to send the manuscript to a third reviewer, and the resultant delay allowed us to add critical information (suggested by Reviewer 2) showing that the hypocretin neurons are intermingled with, but distinct from, neurons expressing the neuropeptide melanin-concentrating hormone (MCH) (Fig. 1). The third reviewer was highly supportive — thank you Reviewer 3, wherever you are! — and our paper was finally accepted for publication and appeared in the December 1, 1998 issue of the Journal of Neuroscience. That same month, two papers were published in the Journal of Comparative Neurology that also demonstrated that the hypocretin/orexin and $\mathrm{MCH}$ cell bodies were coextensive but distinct populations (Broberger et al., 1998; Elias et al., 1998). The following month, a paper mapping the projections of the hypocretin/orexin neurons was published in Proceedings of the National Academy of Sciences of the United States of America (Date et al., 1999). To this day, we remain very grateful to Professor Carew and Reviewer 3 for exercising such good judgment!

Our involvement in the discovery of the hypocretin (orexin) neuropeptides was a conjunction of independent, somewhat haphazard, events. In August 1995, senior author T.S.K. took sabbatical leave from Stanford University to join the laboratory of J. Gregor Sutcliffe at the Scripps Research Institute in La Jolla, California. Sutcliffe's laboratory was actively using the directional tag-PCR subtraction technique to isolate brain region-specific mRNAs (Usui et al., 1994; Gautvik et al., 1996). When T.S.K. entered the laboratory, a hypothalamus versus hippocampus and cerebellum subtraction led by Kaare Gautvik, was well underway. Gautvik suggested to T.S.K. that he should characterize some of the anonymous clones that were emerging from the hypothalamic subtraction, one of which (H35) had a very specific localization within the hypothalamus. Working with Sutcliffe laboratory members Luis de Lecea, Patria Danielson, and Pam Foye, the full-length clone for H35 was isolated from the rat, its cDNA sequence was determined, and similar information was subsequently obtained from the mouse. Whereas three dibasic cleavage sites were found in rat preprohypocretin, only two were conserved in the mouse, suggesting that two neuropeptides were encoded by the mRNA precursor (de Lecea et al., 1998). This information was critical as it enabled the design of antipeptide anti- body 2050 that was used by Peyron et al. (1998) to map the hypocretin cell bodies and their projections. It is a testament both to the immunogenicity of the peptide sequence and the skill within the Sutcliffe laboratory that such high-quality antisera could be made by T.S.K., who had never made an antiserum previously.

After T.S.K. returned to Stanford in August 1996, C.P. joined his group in the Stanford University Sleep Disorders Research Center in October 1996. Because she had acquired a strong background in neuroanatomy during her $\mathrm{PhD}$ training with $\mathrm{Dr}$. Pierre-Hervé Luppi in Prof. Michel Jouvet's laboratory (Lyon, France), she was easily persuaded to lead the preprohypocretin neuroanatomy effort, which resulted in our highly cited paper. Because there was no Neurolucida system available for our use at Stanford to draw the axonal fibers, Dr. Peter O'Hara of the University of California San Francisco graciously allowed C.P. and Devin Tighe to use the system in his laboratory (a 30 mile drive from Stanford). Drawing each of the sections in Peyron et al. (1998) took a full day because of the high density of axonal fibers. All sections were drawn in identical proportion from section to section to provide an accurate visual representation of the fiber density. This was tedious, time-consuming work, considering that 18 brain sections, rostral to caudal, are reported in the paper and many more were drawn than were published! C.P. had to convince T.S.K. that these painstaking efforts were going to be worth the investment. The beauty of the publication results from the fact that the Journal of Neuroscience not only agreed to publish so many figures but also kept them at the original size. As indicated above, a study reporting the orexin projections in the rat brain appeared (Date et al., 1999) shortly after our publication. If our paper is cited 3 times more frequently than the Date et al. (1999) paper, it is likely because we published a very detailed and accurate mapping of the hypocretin/orexin neurons and that the Journal of Neuroscience kindly agreed to follow our specifications.

Ironically, neither we nor the Sakurai/Date/Yanagisawa group were actually the first to map the location and projection of the hypocretin/orexin neurons. The Jouvet laboratory in Lyon, France had been studying the effect of prolactin on sleep regulation and, in 1993, published a neuroanatomical description of "central prolactin neurons" for which they had used an antiserum to ovine prolactin (oPRL) that had been made in the 1970s (Paut-Pagano et al., 1993). Shortly after mapping the mRNA dis- 
tribution of clone H35 in November 1995 while working in Sutcliffe's laboratory, T.S.K. noted its amazingly restricted localization to the hypothalamus and discussed these results with Professor Larry Swanson who referred him to the Paut-Pagano et al. (1993) paper. T.S.K. then wrote to several individuals to obtain an aliquot of this oPRL antiserum but, because of the limited amount remaining, his request was unable to be fulfilled. Nevertheless, after the initial description of the hypocretins by de Lecea et al. (1998), Dr. Pierre-Yves Risold of Centre National de la Recherche Scientifique in France demonstrated the hypothesized colocalization of preprohcrt mRNA and oPRL immunoreactivity and determined that the prolactin peptide sequence used to produce the oPRL antiserum corresponded to an epitope of the preprohypocretin peptide precursor (Risold et al., 1999). Thus, Jouvet's laboratory, world-renowned for its work on the regulation of paradoxical (i.e., REM) sleep, was indeed the first to visualize the hypocretin neurons, a system now known to suppress paradoxical sleep and promote wakefulness, without knowing it!

With respect to the functions of the hypocretin/orexin system, Prof. Masashi Yanagisawa's team at the University of Texas Southwestern Medical School had shown in its first report that orexins promoted feeding (Sakurai et al., 1998). The localization of the hypocretin/orexin neurons in the tuberal hypothalamus, within a region well known to be involved in feeding regulation, and its strong connections with feeding centers, supported these observations and captured the interest of the scientific community. In the first 2 years after their discovery, publications on the hypocretins/orexins primarily focused on their putative function as central mediators of food intake, although it quickly became apparent that their role was not as central as other neuropeptides were (Edwards et al., 1999). It is interesting that, although the orexin/hypocretin peptides play a minor role in food intake, the name "orexin" (derived from the Greek "orexis" meaning appetite) is still widely used, even more widely than hypocretin. "Hypocretin" was chosen to denote the location of the cell bodies in the hypothalamus, as well as the sequence homology of these peptides with the gut peptide secretin.

Because both of us are sleep researchers, our finding that a high density of hypocretin fibers was present in all the brain regions known to be involved in wake promotion, particularly regions containing the adrenergic, noradrenergic, histaminergic, and serotoninergic neurons, suggested to us that these newly identified neurons might play a role in the regulation of the sleep/ wake cycle. As part of the "handwaving arguments in the discussion" noted by Reviewer 2 in our Journal of Neuroscience paper, we indeed suggested a role for the hypocretins in sleep/wake control. However, we had little expectation at the time that these peptides would play such a central role. During these first 2 years, we tried to interest fellow sleep neurobiologists to work on these neuropeptides, particularly because of the intense innervation of the locus ceruleus, but functional data were lacking to convince our colleagues to jump into this area. However, in late July/early August 1999, two key papers were published in Cell indicating that a defect in hypocretin/orexin neurotransmission might be related to the sleep disorder narcolepsy in animal models (Chemelli et al., 1999; Lin et al., 1999). In January 2000, the first observations of low hypocretin-1/orexin-A levels in the CSF of human narcoleptics were published (Nishino et al., 2000), suggesting a problem with either synthesis or release of this peptide in narcoleptic patients. Later that year, two now classic reports demonstrated that the number of hypothalamic neurons synthesizing the hypocretin neuropeptides was greatly reduced in the brain of human narcoleptics (Peyron et al., 2000; Thannickal et al., 2000). Thus, in a little $>2.5$ years, the two hypocretin neuropeptides were discovered, implicated in at least two central functions, linked to animal models of the sleep disorder narcolepsy, and ultimately shown to be the likely proximate cause of this debilitating sleep disorder. Since then, a large body of literature has clarified the role of hypocretin/orexin in the regulation of the sleep/wake cycle (for review, see Schwartz and Kilduff, 2015). Briefly, hypocretin neurons are active only during wakefulness (Lee et al., 2005; Mileykovskiy et al., 2005), and hypocretin-1/ orexin-A is released during wakefulness and sleep deprivation (Zeitzer et al., 2003), particularly during positive emotional states, as demonstrated by intracerebral microdialysis in humans (Blouin et al., 2013). Optogenetic and pharmacogenetic manipulations of orexin neurons have shown that these neuropeptides promote wakefulness by exciting wake-promoting neurons (Adamantidis et al., 2007; Sasaki et al., 2011; Carter et al., 2012).

This line of basic research has led to the production of a new pharmacological treatment for insomnia. Because wakepromoting systems are thought to be overactivated in insomnia patients (Riemann et al., 2015), orexin receptor antagonists were developed to reduce waking drive. Suvorexant (Belsomra) was the first orexin receptor antagonist approved by the U.S. Food and Drug Administration in August 2014 and is now on the market in the United States and Japan.

The establishment of a role for the hypocretin/orexin in reward and addiction is more recent. DiLeone et al. (2003) first suggested this possibility in a review proposing that "Neurons expressing these neuropeptides (i.e., orexin/hypocretin) have extensive projections to regions of the brain important for behavioral responses to drugs of abuse (referring to Peyron et al., 1998), raising the possibility that the pathways may also be important in addiction." The role of orexin/hypocretin peptides in reward was subsequently determined (Boutrel et al., 2005; Harris et al., 2005). Again, these authors stated that their hypotheses were strongly driven by the neuroanatomical observations that we had reported. Today, the role of hypocretins/orexins in reward, drug seeking, and relapse is clearly established (Baimel et al., 2015). Orexin antagonists are considered to be a promising approach for treating substance abuse. The dual involvement of hypocretins in wakefulness and drug-seeking behaviors highlights the need for healthy sleep hygiene in the everyday fight against relapse. Because misuse of hypnotics is prevalent, the putative lack of abuse liability of orexin antagonists represents an advance over current drug treatments for insomnia.

Research on sleep/wake control, addiction, and other fields has been facilitated by the development of multiple mouse models of the hypocretin/orexin system. The orexin/eGFP mouse has enabled study of the neurophysiological control of orexin neurons in vitro (Yamanaka et al., 2003). Some of the best characterized transgenic in vivo models have focused on the pathophysiology of narcolepsy, including the orexin ligand knock-out mouse (Chemelli et al., 1999), the orexin-ataxin 3 mouse (Hara et al., 2001), the orexin receptor-2 null mouse (Willie et al., 2003), and, most recently, the orexin-DTA mouse (Tabuchi et al., 2014). The use of these transgenic models has suggested new therapeutic pathways for the treatment of narcolepsy symptomatology (Black et al., 2014, 2016). However, the loss of hypocretin/orexin neurons in human narcolepsy suggests that the ultimate treatment for this disorder would be hypocretin replacement therapy to compensate for loss of these neuropeptides. Although most drug discovery efforts focusing on hypocretin/orexin agonists have been impeded by the difficulty of finding compounds that penetrate the blood-brain barrier, Nagahara et al. (2015) recently described the first selective nonpeptidergic orexin agonists, 
which may lead to novel therapeutics for the treatment of this disease.

Sixteen years since its first discovery, the cause of hypocretin/ orexin neuronal death in narcolepsy Type 1 is still unknown. The current leading hypothesis is that narcolepsy is an autoimmune disease that specifically targets the hypocretin/orexin neurons rather than the hypocretin/orexin neuropeptides (Singh et al., 2013; Liblau et al., 2015). Although numerous studies have searched for autoantibodies in CSF without success, only very recently have mouse models been developed to decipher the cause of hypocretin/orexin neurodegeneration (Bernard-Valnet et al., 2016; Tesoriero et al., 2016). C.P. and immunologists Roland Liblau and Raphael BernardValnet have recently described an innovative mouse model to study the etiology of narcolepsy that expresses a neo-selfantigen specifically on the membrane of hypocretin/orexin neurons (Bernard-Valnet et al., 2016). Adoptive transfer of effector neo-self-antigen-specific CD8, but not CD4, T cells led to T-cell infiltration of the hypothalamus and specific destruction of hypocretin/orexin neurons, resulting in narcolepsy. These new studies promise a better understanding of the mechanisms involved in the development of narcolepsy, with the hope that it will lead to the development of curative treatments.

In conclusion, as indicated by its citation rate, our paper has clearly impacted several areas of neuroscience research. Although not always considered flashy, solid neuroanatomical studies lay an essential foundation for subsequent functional studies. In recent years, there has been increased focus at the National Institutes of Health and elsewhere on translational research. Although neuroanatomical studies are rarely considered "translational," the hypocretin/orexin story in toto has led to an understanding of the etiology of a sleep disorder that had been a mystery since its original description 120 years earlier and has also led to the development of a new treatment for insomnia. With a little more luck, human narcoleptics may have a new pharmacological treatment within a decade as well!

\section{References}

Adamantidis AR, Zhang F, Aravanis AM, Deisseroth K, de Lecea L (2007) Neural substrates of awakening probed with optogenetic control of hypocretin neurons. Nature 450:420-424. CrossRef Medline

Baimel C, Bartlett SE, Chiou LC, Lawrence AJ, Muschamp JW, Patkar O, Tung LW, Borgland SL (2015) Orexin/hypocretin role in reward: implications for opioid and other addictions. Br J Pharmacol 172:334-348. CrossRef Medline

Bernard-Valnet R, Yshii L, Quériault C, Nguyen XH, Arthaud S, Rodrigues M, Canivet A, Morel AL, Matthys A, Bauer J, Pignolet B, Dauvilliers Y, Peyron C, Liblau RS (2016) CD8 T cell-mediated killing of orexinergic neurons induces a narcolepsy-like phenotype in mice. Proc Natl Acad Sci U S A 113:10956-10961. CrossRef Medline

Black SW, Morairty SR, Chen TM, Leung AK, Wisor JP, Yamanaka A, Kilduff TS (2014) GABAB agonism promotes sleep and reduces cataplexy in murine narcolepsy. J Neurosci 34:6485-6494. CrossRef Medline

Black SW, Schwartz MD, Chen TM, Hoener MC, Kilduff TS (epub ahead of print October 18,2016) TAAR1 agonists as narcolepsy therapeutics. Biol Psychiatry. CrossRef Medline

Blouin AM, Fried I, Wilson CL, Staba RJ, Behnke EJ, Lam HA, Maidment NT, Karlsson KA, Lapierre JL, Siegel JM (2013) Human hypocretin and melanin-concentrating hormone levels are linked to emotion and social interaction. Nat Commun 4:1547. CrossRef Medline

Boutrel B, Kenny PJ, Specio SE, Martin-Fardon R, Markou A, Koob GF, de Lecea L (2005) Role for hypocretin in mediating stress-induced reinstatement of cocaine-seeking behavior. Proc Natl Acad Sci U S A 102: 19168-19173. CrossRef Medline

Broberger C, De Lecea L, Sutcliffe JG, Hökfelt T (1998) Hypocretin/orexinand melanin-concentrating hormone-expressing cells form distinct populations in the rodent lateral hypothalamus: relationship to the neu- ropeptide $\mathrm{Y}$ and agouti gene-related protein systems. J Comp Neurol 402:460-474. CrossRef Medline

Carter ME, Brill J, Bonnavion P, Huguenard JR, Huerta R, de Lecea L (2012) Mechanism for Hypocretin-mediated sleep-to-wake transitions. Proc Natl Acad Sci U S A 109:E2635-E2644. CrossRef Medline

Chemelli RM, Willie JT, Sinton CM, Elmquist JK, Scammell T, Lee C, Richardson JA, Williams SC, Xiong Y, Kisanuki Y, Fitch TE, Nakazato M, Hammer RE, Saper CB, Yanagisawa M (1999) Narcolepsy in orexin knockout mice: molecular genetics of sleep regulation. Cell 98:437-451. CrossRef Medline

Date Y, Ueta Y, Yamashita H, Yamaguchi H, Matsukura S, Kangawa K, Sakurai T, Yanagisawa M, Nakazato M (1999) Orexins, orexigenic hypothalamic peptides, interact with autonomic, neuroendocrine and neuroregulatory systems. Proc Natl Acad Sci U S A 96:748-753. CrossRef Medline

de Lecea L, Kilduff TS, Peyron C, Gao X, Foye PE, Danielson PE, Fukuhara C, Battenberg EL, Gautvik VT, Bartlett FS 2nd, Frankel WN, van den Pol AN, Bloom FE, Gautvik KM, Sutcliffe JG (1998) The hypocretins: hypothalamus-specific peptides with neuroexcitatory activity. Proc Natl Acad Sci U S A 95:322-327. CrossRef Medline

DiLeone RJ, Georgescu D, Nestler EJ (2003) Lateral hypothalamic neuropeptides in reward and drug addiction. Life Sci 73:759-768. CrossRef Medline

Edwards CM, Abusnana S, Sunter D, Murphy KG, Ghatei MA, Bloom SR (1999) The effect of the orexins on food intake: comparison with neuropeptide Y, melanin-concentrating hormone and galanin. J Endocrinol 160:R7-R12. CrossRef Medline

Elias CF, Saper CB, Maratos-Flier E, Tritos NA, Lee C, Kelly J, Tatro JB, Hoffman GE, Ollmann MM, Barsh GS, Sakurai T, Yanagisawa M, Elmquist JK (1998) Chemically defined projections linking the mediobasal hypothalamus and the lateral hypothalamic area. J Comp Neurol 402:442-459. CrossRef Medline

Gautvik KM, de Lecea L, Gautvik VT, Danielson PE, Tranque P, Dopazo A, Bloom FE, Sutcliffe JG (1996) Overview of the most prevalent hypothalamus-specific mRNAs, as identified by directional tag PCR subtraction. Proc Natl Acad Sci U S A 93:8733-8738. CrossRef Medline

Hara J, Beuckmann CT, Nambu T, Willie JT, Chemelli RM, Sinton CM, Sugiyama F, Yagami K, Goto K, Yanagisawa M, Sakurai T (2001) Genetic ablation of orexin neurons in mice results in narcolepsy, hypophagia, and obesity. Neuron 30:345-354. CrossRef Medline

Harris GC, Wimmer M, Aston-Jones G (2005) A role for lateral hypothalamic orexin neurons in reward seeking. Nature 437:556-559. CrossRef Medline

Lee MG, Hassani OK, Jones BE (2005) Discharge of identified orexin/hypocretin neurons across the sleep-waking cycle. J Neurosci 25:6716-6720. CrossRef Medline

Liblau RS, Vassalli A, Seifinejad A, Tafti M (2015) Hypocretin (orexin) biology and the pathophysiology of narcolepsy with cataplexy. Lancet Neurol 14:318-328. CrossRef Medline

Lin L, Faraco J, Li R, Kadotani H, Rogers W, Lin X, Qiu X, de Jong PJ, Nishino S, Mignot E (1999) The sleep disorder canine narcolepsy is caused by a mutation in the hypocretin (orexin) receptor 2 gene. Cell 98:365-376. CrossRef Medline

Mileykovskiy BY, Kiyashchenko LI, Siegel JM (2005) Behavioral correlates of activity in identified hypocretin/orexin neurons. Neuron 46:787-798. CrossRef Medline

Nagahara T, Saitoh T, Kutsumura N, Irukayama-Tomobe Y, Ogawa Y, Kuroda D, Gouda H, Kumagai H, Fujii H, Yanagisawa M, Nagase H (2015) Design and synthesis of non-peptide, selective orexin receptor 2 agonists. J Med Chem 58:7931-7937. CrossRef Medline

Nishino S, Ripley B, Overeem S, Lammers GJ, Mignot E (2000) Hypocretin (orexin) deficiency in human narcolepsy. Lancet 355:39-40. CrossRef Medline

Paut-Pagano L, Roky R, Valatx JL, Kitahama K, Jouvet M (1993) Anatomical distribution of prolactin-like immunoreactivity in the rat brain. Neuroendocrinology 58:682-695. Medline

Peyron C, Tighe DK, van den Pol AN, de Lecea L, Heller HC, Sutcliffe JG, Kilduff TS (1998) Neurons containing hypocretin (orexin) project to multiple neuronal systems. J Neurosci 18:9996-10015. Medline

Peyron C, Faraco J, Rogers W, Ripley B, Overeem S, Charnay Y, Nevsimalova S, Aldrich M, Reynolds D, Albin R, Li R, Hungs M, Pedrazzoli M, Padigaru M, Kucherlapati M, Fan J, Maki R, Lammers GJ, Bouras C, Kucherlapati R, et al. (2000) A mutation in a case of early onset narcolepsy and 
a generalized absence of hypocretin peptides in human narcoleptic brains. Nat Med 6:991-997. CrossRef Medline

Riemann D, Nissen C, Palagini L, Otte A, Perlis ML, Spiegelhalder K (2015) The neurobiology, investigation, and treatment of chronic insomnia. Lancet Neurol 14:547-558. CrossRef Medline

Risold PY, Griffond B, Kilduff TS, Sutcliffe JG, Fellmann D (1999) Preprohypocretin (orexin) and prolactin-like immunoreactivity are coexpressed by neurons of the rat lateral hypothalamic area. Neurosci Lett 259:153156. CrossRef Medline

Sakurai T, Amemiya A, Ishii M, Matsuzaki I, Chemelli RM, Tanaka H, Williams SC, Richardson JA, Kozlowski GP, Wilson S, Arch JR, Buckingham RE, Haynes AC, Carr SA, Annan RS, McNulty DE, Liu WS, Terrett JA, Elshourbagy NA, Bergsma DJ, et al. (1998) Orexins and orexin receptors: a family of hypothalamic neuropeptides and G protein-coupled receptors that regulate feeding behavior. Cell 92:573-585. CrossRef Medline

Sasaki K, Suzuki M, Mieda M, Tsujino N, Roth B, Sakurai T (2011) Pharmacogenetic modulation of orexin neurons alters sleep/wakefulness states in mice. PLoS One 6:e20360. CrossRef Medline

Schwartz MD, Kilduff TS (2015) The neurobiology of sleep and wakefulness. Psychiatr Clin North Am 38:615-644. CrossRef Medline

Singh AK, Mahlios J, Mignot E (2013) Genetic association, seasonal infections and autoimmune basis of narcolepsy. J Autoimmun 43:26-31. CrossRef Medline

Tabuchi S, Tsunematsu T, Black SW, Tominaga M, Maruyama M, Takagi K, Minokoshi Y, Sakurai T, Kilduff TS, Yamanaka A (2014) Conditional ablation of orexin/hypocretin neurons: a new mouse model for the study of narcolepsy and orexin system function. J Neurosci 34:6495-6509. CrossRef Medline

Tesoriero C, Codita A, Zhang MD, Cherninsky A, Karlsson H, GrassiZucconi G, Bertini G, Harkany T, Ljungberg K, Liljeström P, Hökfelt TG, Bentivoglio M, Kristensson K (2016) H1N1 influenza virus induces narcolepsy-like sleep disruption and targets sleep-wake regulatory neurons in mice. Proc Natl Acad Sci U S A 113:E368-377. CrossRef Medline

Thannickal TC, Moore RY, Nienhuis R, Ramanathan L, Gulyani S, Aldrich M, Cornford M, Siegel JM (2000) Reduced number of hypocretin neurons in human narcolepsy. Neuron 27:469-474. CrossRef Medline

Usui H, Falk JD, Dopazo A, de Lecea L, Erlander MG, Sutcliffe JG (1994) Isolation of clones of rat striatum-specific mRNAs by directional tag PCR subtraction. J Neurosci 14:4915-4926. Medline

Willie JT, Chemelli RM, Sinton CM, Tokita S, Williams SC, Kisanuki YY, Marcus JN, Lee C, Elmquist JK, Kohlmeier KA, Leonard CS, Richardson JA, Hammer RE, Yanagisawa M (2003) Distinct narcolepsy syndromes in Orexin receptor-2 and Orexin null mice: molecular genetic dissection of Non-REM and REM sleep regulatory processes. Neuron 38:715-730. CrossRef Medline

Yamanaka A, Muraki Y, Tsujino N, Goto K, Sakurai T (2003) Regulation of orexin neurons by the monoaminergic and cholinergic systems. Biochem Biophys Res Commun 303:120-129. CrossRef Medline

Zeitzer JM, Buckmaster CL, Parker KJ, Hauck CM, Lyons DM, Mignot E (2003) Circadian and homeostatic regulation of hypocretin in a primate model: implications for the consolidation of wakefulness. J Neurosci 23: 3555-3560. Medline 